\title{
Notes
}

\section{Notes to the Introduction}

I See Nathan Hensley's summation in 'Figures of Reading', Criticism 54, no. 2 (2012): 329-42, especially 329-30. 'Should the reading we do be close or distant? Deep or superficial? Fast or slow? And is literature information or something, well, better?'

2 See the discussion on 'symptomatic' reading in Stephen Best and Sharon Marcus, 'Surface Reading: An Introduction', Representations io8, no. I (2009): I-2I; see also the discussions on 'critical' and 'suspicious' reading (and their alternatives) in Rita Felski, 'After Suspicion', Profession (2009): 28-35 and in Rita Felski, The Limits of Critique (Chicago: University of Chicago Press, 2015), especially I4-20 and I07-I6.

3 Rita Felski, Uses of Literature (Oxford: Blackwell, 2009), 76.

4 Elaine Auyoung, When Fiction Feels Real: Representation and the Reading Mind (Oxford: Oxford University Press, 2018), 20.

5 Brigid Lowe, Victorian Fiction and the Insights of Sympathy: An Alternative to the Hermeneutics of Suspicion (London: Anthem Press, 2007), I 2.

6 Charles Dickens, David Copperfield, ed. Nina Burgis (Oxford: Clarendon Press, I98I), 48.

7 William Makepeace Thackeray, Vanity Fair, ed. Helen Small (Oxford: Oxford University Press, 2015), 878.

8 Charlotte Brontë, Jane Eyre, ed. Jane Jack and Margaret Smith (Oxford: Clarendon Press, 1969), I32. Further references to this edition will be incorporated into the text.

9 Eve Kosofsky Sedgwick, Touching Feeling: Affect, Pedagogy, Performativity (Durham, NC: Duke University Press, 2003), I 50.

Io George Henry Lewes, 'Dickens in Relation to Criticism', Fortnightly Review I I, no. 62 (I872): I 46.

I I Sigmund Freud, 'Creative Writers and Day-Dreaming', in Pelican Freud Library, ed. James Strachey, vol. I4 (Harmondsworth: Penguin, I985), I 3 I.

I 2 Peter Brooks, Realist Vision (New Haven, CT: Yale University Press, 2005), 3.

I 3 Thomas Pavel, Fictional Worlds (Cambridge, MA: Harvard University Press, I989), 55. 
I4 Gilles Deleuze, Difference and Repetition, trans. Paul Patton (London: Bloomsbury, 20I4), 272. For Deleuze, however, the term refers more specifically to the reality of states of potential, rather than the sense of pretended, artificial, or mediated reality explored here and in the concept's broader usage in cultural studies (as I go on to explain). See Paul Patton, Deleuze and the Political (London: Routledge, 2000), 35-36.

I 5 John Plotz, Semi-Detached: The Aesthetics of Virtual Experience since Dickens (Princeton: Princeton University Press, 2018), I6.

I6 Jean-Marie Schaeffer, Why Fiction?, trans. Dorrit Cohn (Lincoln: University of Nebraska Press, 20I0), x: '[V]irtualisation is by no means an invention of the digital era [...] every mental representation is a virtual reality. There is thus definitely a link between the virtual and fiction; being a particular modality of representation, fiction is at the same time a specific form of the virtual'. See also Elizabeth A. Grosz's argument in Architecture from the Outside: Essays on Virtual and Real Space (Cambridge, MA: MIT Press, 200I), 77. '[T] he virtual reality of writing, reading, drawing or even thinking [...] loads the presence of the present with supplementarity, redoubling a world through parallel universes, universes that might have been', as quoted in Peter Otto, Multiplying Worlds: Romanticism, Modernity, and the Emergence of Virtual Reality (Oxford: Oxford University Press, 20II), 6.

I7 Otto, Multiplying Worlds, 7-I4.

I 8 Plotz, Semi-Detached, I6.

I9 William Gibson, Neuromancer (New York: Berkley Publishing Group, I989), I 28.

20 William Makepeace Thackeray, Roundabout Papers (London: J. M. Dent \& Sons, I9I4), 273.

2 I J. David Velleman, 'Bodies, Selves', American Imago 65, no. 3 (2008): 407, emphasis added; for other examples of fictional-literal actions in the context of ethics - e.g., virtual adultery with fictional persons - see Charles M. Ess, 'Ethics at the Boundaries of the Virtual', in The Oxford Handbook of Virtuality, ed. Mark Grimshaw (Oxford: Oxford University Press, 20I4), 69I.

22 Auyoung, When Fiction Feels Real, 2.

23 Terence Cave, Thinking with Literature: Towards a Cognitive Criticism (Oxford: Oxford University Press, 20I6), 48, original emphasis; see also Caroline Levine, Forms: Whole, Rhythm, Hierarchy, Network (Princeton: Princeton University Press, 2015), 6.

24 Catherine Gallagher, 'The Rise of Fictionality', in The Novel, ed. Franco Moretti (Princeton: Princeton University Press, 2006), 340; Lennard J. Davis, Factual Fictions: The Origins of the English Novel (Philadelphia: University of Pennsylvania Press, I983), I 56.

25 Elaine Freedgood, 'Fictional Settlements: Footnotes, Metalepsis, the Colonial Effect', New Literary History 4I, no. 2 (2010): 394.

26 Lennard J. Davis, Resisting Novels (New York: Routledge, I987), 2. 
27 Michael Saler, As If: Modern Enchantment and the Literary Prehistory of Virtual Reality (Oxford: Oxford University Press, 20II), 32; Lowe, Insights of Sympathy, 82.

28 Henry Fielding, The Wesleyan Edition of the Works of Henry Fielding: Joseph Andrews, ed. Martin C. Battestin (Oxford: Oxford University Press and Wesleyan University Press, I966), I 89; Gallagher, 'Rise of Fictionality', 342.

29 Lowe, Insights of Sympathy, 78; see Michael Warner's reflections on teaching critical reading, in 'Uncritical Reading', in Polemic: Critical or Uncritical, ed. Jane Gallop (New York: Routledge, 2004), I3-I 5.

30 As Richard Walsh similarly argues, 'What we understand, feel, and value [in fiction] may be ultimately grounded in the abstract and the general, but it is not in general terms that we experience understanding, feeling, or valuing it. Fiction enables us to go through that process, for the sake of its experience'. The Rhetoric of Fictionality: Narrative Theory and the Idea of Fiction (Columbus: Ohio State University Press, 2007), 5 I.

3 I William Charles Macready, The Journal of William Charles Macready, I832-I85I, ed. J. C. Trewin (Carbondale: Southern Illinois University Press, 2009), I69; Charles Dickens, The Letters of Charles Dickens, I840-I84I, ed. Madeline House, Graham Storey, and Kathleen Tillotson, vol. 2 (Oxford: Clarendon Press, I969), I 8 I.

32 Macready, Journal, I832-I851, I69.

33 Dickens, Letters $1840-I 84 I$, 2: x, original emphasis.

34 Lesley Anne Goodman, 'Indignant Reading' (PhD diss., Harvard University, 2013), 26, original emphasis.

35 Lowe, Insights of Sympathy, I2; Wayne Booth, The Company We Keep: An Ethics of Fiction (Berkeley: University of California Press, I988), 256; see also Martha Nussbaum's reflections on experiencing love for David Copperfield s Steerforth, from reciting the words of a besotted character (David himself) in the first person, in Love's Knowledge (Oxford: Oxford University Press, I992), 335 .

36 Velleman, 'Bodies, Selves', 407.

37 Charles Dickens, The Mudfog Papers (London: Richard Bentley and Son, I880), I33-34.

38 Dickens, I $35-36$.

39 Charles Dickens, The Letters of Charles Dickens, I847-1849, ed. Graham Storey, K. J. Fielding, and Anthony Laude, vol. 5 (Oxford: Clarendon Press, I 977), 640.

40 Rae Greiner, Sympathetic Realism in Nineteenth-Century British Fiction (Baltimore: Johns Hopkins University Press, 201 2), Io.

4I Jonathan Farina, “'Dickens's As If”: Analogy and Victorian Virtual Reality', Victorian Studies 53, no. 3 (201 I): 429, original emphasis.

42 Freedgood, 'Fictional Settlements', 407-8.

43 Nicholas Dames, 'On Hegel, History, and Reading as If for Life: Response', Victorian Studies 53, no. 3 (20 I I): 437-44, https://doi.org/IO.I353/vic.20 I I .0044 . 


\section{Notes to Chapter One}

I William Makepeace Thackeray, The History of Pendennis: His Fortunes and Misfortunes, His Friends and His Greatest Enemy, ed. John A. Sutherland (Oxford: Oxford University Press, I994), 53 I.

2 The most formalised version of this idea is known as the possible worlds theory of fiction, which uses the tools of modal logic to explain how we refer concretely to hypothetical, counterfactual, and fictional states of affairs. The narratological scholarship around this theory aims to solve other kinds of problems - of narrative semantics and typology - than this book's focus on the novel form and its criticism, but the two share an interest in the ontology of fictional language. See Marie-Laure's Ryan's bibliographical survey in 'Possible Worlds in Recent Literary Theory', Style 4, no. 26 (1992): 528-53; Ruth Ronen's study Possible Worlds in Literary Theory (Cambridge: Cambridge University Press, 1994). For a more recent discussion, see MarieLaure Ryan, 'From Parallel Universes to Possible Worlds: Ontological Pluralism in Physics, Narratology, and Narrative', Poetics Today 27, no. 4 (2006): 633-74.

3 Michael McKeon, 'The Eighteenth-Century Challenge to Narrative Theory', in Narrative Concepts in the Study of Eighteenth-Century Literature, ed. Liisa Steinby and Aino Mäkikalli (Amsterdam: University of Amsterdam Press, 20I7), 4I.

4 Jonathan Rose, The Intellectual Life of the British Working Classes (New Haven, CT: Yale University Press, 200I), 94.

5 Rose quotes a range of examples, from a nineteenth-century joiner's son: 'characters in the book have always been historical characters with me, just as real as Caius Julius Caesar [... I I believed every word it contained. I never saw a novel before. I did not know the meaning of fiction.' The minister Joseph Barker: 'I doubted nothing that I found in books [...] I had no idea at the time I read Robinson Crusoe, that there were such things as novels, works of fiction, in existence.' See Rose, 92-102; for the philosophical confusion of Sherlock Holmes's fictional existence in factual London, see David Lewis, 'Truth in Fiction', American Philosophical Quarterly I 5, no. I (I978): 37-46.

6 Gallagher, 'Rise of Fictionality', 34I.

7 J. Jeffrey Franklin, Serious Play: The Cultural Form of the Nineteenth-Century Realist Novel (Philadelphia: University of Pennsylvania Press, 1999), 4; for an overview of play as a cultural concept more generally, see also Matthew Kaiser, The World in Play: Portraits of a Victorian Concept (Stanford, CA: Stanford University Press, 201 I), I $3-49$.

8 Gallagher, 'Rise of Fictionality', 336-37.

9 Rose, Intellectual Life, 94.

Io Thomas De Quincey, 'Autobiographical Sketches' in The Works of Thomas De Quincey, ed. Daniel Sanjiv Roberts, vol. I9 (London: Pickering \& Chatto, 2003), 45. Further references to this edition will be incorporated into the text. 
I I Both of the brothers' islands lack a longitudinal coordinate because the universal Prime Meridian (the zero point of longitude) would not be established in Greenwich until I 884.

I 2 Sally Shuttleworth, The Mind of the Child: Child Development in Literature, Science, and Medicine, I840-I90o (Oxford: Oxford University Press, 2013), 82.

I3 Daniel Defoe, Robinson Crusoe, ed. Thomas Keymer and James Kelly (Oxford: Oxford University Press, 2007), 4, 276n. The first and second editions have 'dispatch'd' instead of 'disputed'. See Keymer and Kelly's explanatory note.

I4 Putting aside the ongoing contentiousness of his wider history of the form, Watt's account incisively identifies the novel's fictional informativeness as 'its most distinctive literary qualities': 'the premise, or primary convention, that the novel is a full and authentic report of human experience [...] with such details of the story as the individuality of the actors concerned, the particulars of the times and places of their actions [...] presented through a more largely referential use of language than is common in other literary forms'. The Rise of the Novel: Studies in Defore, Richardson and Fielding (London: Pimlico, 200o), 32-33. As Michael Seidel has argued, despite the numerous revisions and criticisms on Watt's model of realism, 'no one, to my knowledge, has ever convincingly displaced Watt's notion of formal realism as a dominant characteristic of narrative during the early eighteenth century, particularly in England'. See 'The Man Who Came to Dinner: Ian Watt and the Theory of Formal Realism', Eighteenth-Century Fiction I 2, no. 2-3 (2000): 194.

I 5 Walter Scott, Introductions and Notes from the Magnum Opus: Waverley to A Legend of the Wars of Montrose, ed. J. H. Alexander, P. D. Garside, and Claire Lamont (Edinburgh: Edinburgh University Press, 201 2), 335, 343.

I6 'Memoir of Hartley Coleridge' in Hartley Coleridge, Poems, ed. Derwent Coleridge, vol. I (London: Edward Moxon, I85I), xlii. Further references to this volume and edition will be incorporated into the text.

I7 Benjamin Heath Malkin, A Father's Memoirs of His Child (London: Longman, Hurst, Rees, and Orme, I 806), 93-94.

I 8 Anna Jameson, A Commonplace Book of Thoughts, Memories, and Fancies (London: Longman, Brown, Green, and Longmans, I 855 ), I 3 I.

I9 Jameson, Commonplace Book, I35.

20 Jameson, Commonplace Book, I32. As Patricia Meyer Spacks has suggested of the eighteenth century, 'privacy is a peculiarly emphatic issue for [...] women, both within fiction (e.g., Clarissa) and as writers of fiction, poetry, and diaries'. Gendered implications of interiority, education, and sociality clearly intervene in Jameson's expression of this practice. See Privacy: Concealing the Eighteenth-Century Self (Chicago: University of Chicago Press, 2003), 25.

2 I Charlotte Brontë, Villette, ed. Margaret Smith and Herbert Rosengarten (Oxford: Clarendon Press, I984), I05.

22 Jameson, Commonplace Book, I 35. 
23 Shuttleworth, Mind of the Child, 79.

24 Shuttleworth, Mind of the Child, 79.

25 Their close succession led an anonymous reviewer of Jameson's Commonplace Book to recognise her account of play as the example of a known category, being 'like Hartley Coleridge with his dreamland Ejuxria, like Thomas De Quincey with his dreamland Gombroon'. 'Mrs Jameson's Common-Place Book', The New Monthly Magazine I03 (I 855): I96.

26 See Michele Root-Bernstein's account of this study in Inventing Imaginary Worlds: From Childhood Play to Adult Creativity Across the Arts and Sciences (Lanham, MD: Rowman \& Littlefield Education, 2014), 69-73.

27 'What, if any, effect [...] the elaboration of the imaginary land, may exert on character formation and habits of adjustment in adulthood is at present unknown'. The studies that follow might be seen as a taking-up of this challenge. Leta S. Hollingworth, Children Above I80 IQ (Stanford-Binet): Origin and Development (London: George G. Harrap \& Company, I942), 275 .

28 David Cohen and Stephen A. MacKeith, The Development of Imagination: The Private Worlds of Childhood (London: Routledge, I99I), I I-I4.

29 Cohen and MacKeith, Development of Imagination, 23.

30 See her hypotheses on 'Rates of Worldplay', 'Disciplinary Inclinations', and 'Perceptions of Connection' [between worldplay and creativity] in RootBernstein, Inventing Imaginary Worlds, 42-52.

3 I Her study also produces a tabled list of historical cases, which organises the names and dates of children alongside columns on their 'Imaginary World' and 'Adult Endeavor'. See Root-Bernstein, Inventing Imaginary Worlds, 2I I-I 5 .

32 Christine Alexander, 'Nineteenth-Century Juvenilia: A Survey', in The Child Writer from Austen to Woolf, ed. Christine Alexander and Juliet McMasters (Cambridge, UK: Cambridge University Press, 2005), I I.

33 Joetta Harty, 'The Islanders: Mapping Paracosms in the Early Writings of Hartley Coleridge, Thomas Malkin, Thomas De Quincey, and the Brontes' (PhD diss., The George Washington University, 2007), 3.

34 Although I describe this as a transmission of narrative convention and form from colonial adventure to play, Freedgood has argued that the fictionality of the realist novel involves 'an ontological imperialism' mimetic of (and involved in) other kinds of imperial relationality in this period. Freedgood, 'Fictional Settlements', 394.

35 Defoe, Robinson Crusoe, 4.

36 Kate E. Brown, 'Beloved Objects: Mourning, Materiality, and Charlotte Brontë's 'Never-Ending Story', ELH 65, no. 2 (I998): 403; The Letters of Mrs Gaskell, ed. J. A. V. Chapple and Arthur Pollard (Manchester: Manchester University Press, I 966), 398.

37 Gaskell, Letters, 398. In the next chapter, I suggest Gaskell's ambivalences are grounded in a model of Brontë's realism, and of women's novel-writing more generally, which she seeks to defend. 
38 Fannie Ratchford, The Brontes' Web of Childhood (New York: Columbia University Press, I94I), xiv.

39 'Introduction' in Charlotte Brontë et al., Tales of Glass Town, Angria, and Gondal, ed. Christine Alexander (Oxford: Oxford University Press, 2010), xliii.

40 See the account given in Ratchford, The Brontes' Web of Childhood, 65.

4I After receiving William's publication about the secret tails of his Gombroonians, De Quincey writes: 'Overwhelming to me and stunning was the ignominy of this horrible discovery' $(A S$ 52).

42 'Then, around the turn of the nineteenth century, there was a last change last in the sense that I think we are still in it, not last in the sense of perfect or final. This change is what I'm calling fiction - works that make no bones about their invention despite being set within contemporary reality. (This last trait clearly separates fiction from the 'fanciful' genres of the fairy tale or the oriental tale, as well as from allegory.)' Nicholas D. Paige, Before Fiction: The Ancien Régime of the Novel (Philadelphia: University of Pennsylvania Press, 20II), 26.

43 Catherine Gallagher, 'What Would Napoleon Do?: Historical, Fictional, and Counterfactual Characters', New Literary History 42, no. 2 (20I I): 332.

44 Gallagher's study on the alternative history genre makes this distinction, against the narratological models of Ryan and Doležel, arguing that 'we don't read most novels as counterfactual conjectures; we intuitively make a distinction between the kind of hypothetical exercises involved in counterfactuals and mere fictionality.' Gallagher, 'What Would Napoleon Do?' 333. This chapter argues, however, that 'mere fictionality' is more distinct and complicated than Gallagher acknowledges.

45 Gallagher, 'Rise of Fictionality', 34I.

46 Dickens, David Copperfield, 48.

47 Watt, Rise of the Novel, I9.

48 Gallagher, 'Rise of Fictionality', 337.

49 Jeremy Bentham, The Works of Jeremy Bentham: Memoirs, ed. John Bowring, vol. Io (Edinburgh: William Tait, I 843), 2 I.

50 Jeremy Bentham, The Works of Jeremy Bentham: Chrestomathia, Ontology, Logic, ed. John Bowring, vol. 8 (Edinburgh: William Tait, I84I), $262 \mathrm{fn}$.

5I Saler has also identified this moment of conceptualisation - the invention of explicitly imaginary facts - as an encounter between a Weberian model of modern disenchantment, exemplified here by Bentham's purge of non-actual or non-literal truths, and a re-enchantment of the world and everyday life through forms of make-believe. By using paracosmic play as the signal phenomenon, I locate this moment earlier in literary history than Saler's focus on the fictional worlds of Arthur Conan Doyle, H. P. Lovecraft, and J. R. R. Tolkien. See Saler, As If, 8-I I.

52 Jason Pearl, Utopian Geographies and the Early English Novel (Charlottesville: University of Virginia Press, 2014), I I, I 37.

53 Malkin, Father's Memoir, 69. 
54 See Terence Cave's argument that 'The paratextual material [of Utopia] seems designed to foster the illusion of Utopia as a new or new-found island, but this is especially true of the map and the alphabet [...] [which] is of course essential to the way the work as a whole commutes between the 'ideal' world of Utopia and the lived reality of the early sixteenth century.' Thomas More's Utopia in Early Modern Europe: Paratexts and Contexts (Manchester: Manchester University Press, 2008), 2I-22. For a discussion of belief and evidence in Utopia, see Emmanouil Aretoulakis, 'The Prefatory/ Postscript Letters to St. Thomas More's Utopia: The Culture of 'Seeing' as a Reality-Conferring Strategy', Journal of Early Modern Studies, no. 3 (2014): 9I-II3.

55 Thomas More, Utopia, ed. George M. Logan, trans. Robert M. Adams (Cambridge: Cambridge University Press, 2016), I 29.

56 Pearl, Utopian Geographies, I I7.

57 Pearl, Utopian Geographies, I I.

58 "ideal, Adj. 4.", OED Online (Oxford University Press, 2010), www.oed .com/view/Entry/90958, accessed I9 June 2018.

59 Trollope writes that 'This had been the occupation of my life for six or seven years before I went to the Post Office', $(A A 33)$ which he joined as a clerk in I 834 - placing the start of play around I 827 - and he later notes that ' $U p$ to this time [I 843] I had continued that practice of castle-building of which I have spoken' (49), making roughly sixteen years of castles in all.

60 Jameson, Commonplace Book, I 3 I.

6I J. Hillis Miller, On Literature (London: Routledge, 2002), 53.

62 Cohen and MacKeith, Development of Imagination, IO-I I.

63 Root-Bernstein, Inventing Imaginary Worlds, 4I.

64 Eric Hayot, On Literary Worlds (Oxford: Oxford University Press, 201 2), 66.

65 Hayot, On Literary Worlds, 65-66.

66 Hillis Miller similarly articulates the intuitive sense that the novel 'give[s] the reader access to a realm that seems to exist apart from the words, even though the reader cannot enter it except by way of the words'. On Literature, 54.

67 Paige, Before Fiction, 3 I-32.

\section{Notes to Chapter 2}

I Gaskell, Letters, 398.

2 Elizabeth Gaskell, The Life of Charlotte Bronte, ed. Elisabeth Jay (London: Penguin, I997), 69 Further references to this edition will be incorporated into the text.

3 That Eliot's essay, published during the writing of the Life, singles out Brontë and Gaskell (alongside Harriet Martineau) as women writers who do commit to these qualities of excellence may have given ballast to Gaskell's associations of Brontë's writing with manual and domestic labour, with the 'patient analysis of cause and effect', and with her own prose. George Eliot, 'Silly 
Novels by Lady Novelists', in Essays of George Eliot, ed. Thomas Pinney (New York: Columbia University Press, I963), 323.

4 Eliot, 'Silly Novels by Lady Novelists', 3O I-2; Eliot's focus on difficulty, both of novel-writing and of the feminine accomplishments indulgently represented in novels, reflects an antipathy to art's deprecation into facile recreation. Her critique is embodied by Gwendolen Harleth, who wishes 'I could write books to amuse myself [...] How delightful it must be to write books after one's own taste instead of reading other people's! Home-made books must be so nice'. Gwendolen discovers, in the same chapter, that her soprano is nothing extraordinary in the judgement of a trained musician. Daniel Deronda, ed. Graham Handley (Oxford: Clarendon Press, I984), 39.

5 Q. D. Leavis, Fiction and the Reading Public (London: Chatto \& Windus, I978), 237.

6 Vladimir Nabokov, Lectures on Russian Literature (London: Weidenfeld and Nicolson, I982), Io6.

7 Lowe, Insights of Sympathy, 82.

8 Nabokov, Russian Literature, 106.

9 J. R. R. Tolkien, Tolkien on Fairy-Stories, ed. Verlyn Flieger and Douglas A. Anderson (London: HarperCollins, 2014), 52.

Io Tolkien, Tolkien on Fairy-Stories, 42.

I I M. H. Abrams, The Mirror and the Lamp: Romantic Theory and the Critical Tradition (London: Oxford University Press, I953), 272.

I 2 Elder Olson, "Sailing to Byzantium": Prolegomena to a Poetics of the Lyric', The University of Kansas City Review 8, no. 3 (1942): 216-17; quoted in Abrams, 284.

I 3 Abrams, The Mirror and the Lamp, $384 \mathrm{fn}$.

I4 Nabokov, Russian Literature, Io6.

I 5 Gallagher, 'Rise of Fictionality', 337.

I6 Charlotte Brontë, The Letters of Charlotte Brontë, I848-I85I, ed. Margaret Smith (Oxford: Clarendon Press, 2000), 98.

I7 Brontë, The Letters of Charlotte Brontë, 98, emphasis added.

I 8 Charlotte Brontë, The Early Writings of Charlotte Brontë, I826-I832, ed. Christine Alexander (Padstow: Shakespeare Head Press, 1987), 5-6. Further references to this edition will be incorporated into the text.

I9 Firdous Azim, The Colonial Rise of the Novel (London: Routledge, I993), I 6.

20 Pavel, Fictional Worlds, 56.

2 I Meg Harris Williams, 'Book Magic: Aesthetic Conflicts in Charlotte Brontë's Juvenilia', Nineteenth-Century Literature 42, no. I (I987): 32.

22 Olson, 'Sailing to Byzantium', 216-I7; quoted in Abrams, 284.

23 See also Bock's and Heather Glen's respective discussions of 'Strange Events', a juvenilia tale where the protagonist begins to suspect their own nonexistence. Carol Bock, Charlotte Brontë and the Storyteller's Audience (Iowa City: University of Iowa Press, I992), 33-36; Heather Glen, Charlotte Brontë: The Imagination in History (Oxford: Oxford University Press, 2004), I3-I6. 
24 Laura Forsberg, 'The Miniature World of Charlotte Brontë's Glass Town', in Charlotte Bronte from the Beginnings: New Essays from the Juvenilia to the Major Works, ed. Judith E. Pike and Lucy Morrison (Oxford: Routledge, 20I6), 5 I.

25 Glen, Imagination in History, I I, I9.

26 Dickens, Letters, 620.

27 Forsberg, 'Miniature World', 57.

28 Eliot, 'Lady Novelists', 323; George Eliot, Adam Bede, ed. Carol A. Martin (Oxford: Clarendon Press, 200I), 7.

29 Frank Kermode, Essays on Fiction I97I-82 (Oxford: Routledge Revivals, 20I5), II4.

30 Jane Moore, 'Problematising Postmodernism', in Critical Dialogues: Current Issues in English Studies in Germany and Britain, ed. Isobel Armstrong and Hans-Werner Ludwig (Tubingen: Gunter Narr Verlag Tubingen, I995), I 39. The agent of this act, in Moore's analysis, is unclear; something which 'texts are compelled to perform' due to the inherent nature of fictional language. My own approach is to understand novelists as exploiting the authorial power afforded by fictional realities.

3 I J. Hillis Miller, Reading for Our Time: 'Adam Bede' and 'Middlemarch' Revisited (Edinburgh: Edinburgh University Press, 2012), I 3.

32 George Levine, The Realistic Imagination: English Fiction from Frankenstein to Lady Chatterly (Chicago: University of Chicago Press, I98 I), 56.

33 Levine, The Realistic Imagination, 56.

34 Gérard Genette, Narrative Discourse, ed. Jane E. Lewin and Jonathan Culler (Oxford: Basil Blackwell, I980), 234-35.

35 Genette, Narrative Discourse, 234-35.

36 Gustave Flaubert, The Letters of Gustave Flaubert, I830-I857, ed. and trans. Francis Steegmuller (London: Faber \& Faber, I979), I73.

37 Dorothy L. Sayers, The Mind of the Maker (London: Methuen, I94I), 62-63.

38 Nabokov, Russian Literature, Io6.

39 Jacques Rancière, The Flesh of Words: The Politics of Writing, trans. Charlotte Mandell (Stanford: Stanford University Press, 2004), 72.

40 Rancière, The Flesh of Words, 73.

4I Roland Barthes, The Rustle of Language, trans. Richard Howard (Berkeley: University of California Press, I989), 54.

42 Barthes, The Rustle of Language, 52.

43 Rancière, The Flesh of Words, 72.

44 See Bock's similar reading of this moment: 'For young Charlotte, to make books was to stand in the epistemological space where the actual and the imaginary overlap, creating a third reality in the storytelling situation'. Storyteller's Audience, $3 \mathrm{I}$.

45 Levine, Realistic Imagination, I 5, emphasis added.

46 Levine, Realistic Imagination, 8.

47 Levine, Realistic Imagination, I 5.

48 Dames, 'On Hegel'. 
49 'Introduction' in Charlotte Brontë, Jane Eyre, ed. Mary Augusta Arnold Ward (New York: Harper Bros., I 899), x.

50 Anne Thackeray Ritchie, Chapters from Some Memoirs (London: MacMillan and Co., I 894), 64.

5 I Gaskell, Letters, 400-40I.

52 'The Professor', Examiner, June 20, I 857, 388 ; R. H. Hutton, 'Novels by the Authoress of "John Halifax", North British Review, no. 29 (I 859): 474; 'The Professor', Critic, June I 5, I857, 27I; quoted in Catherine Malone, "We Have Learnt to Love Her More than Her Books": The Critical Reception of Brontë's Professor', The Review of English Studies 47, no. I86 (I996): I77, I8I.

53 Henry Houston Bonnell, Charlotte Brontë, George Eliot, and Jane Austen: Studies in Their Work (New York: Longmans, Green, and Co., I902), 35.

54 Barthes, The Rustle of Language, 54.

55 Charlotte Brontë, The Professor, ed. Margaret Smith and Herbert Rosengarten (Oxford: Clarendon Press, I987), 22 I. Further references to this edition will be incorporated into the text.

56 Dames, 'On Hegel'.

57 Leavis, The Reading Public, I88.

58 Leavis, The Reading Public, 189-90.

59 'Introduction' in Charlotte Brontë, The Professor, ed. Heather Glen (London: Penguin, 2003), $3 \mathrm{I}$.

60 Glen, Imagination in History, 57-58.

6 I Glen, Imagination in History, 58.

62 Leavis, The Reading Public, I 88.

63 Barthes, The Rustle of Language, 54.

64 Levine, Realistic Imagination, I 5; Brontë, The Professor, 2003, 3 I.

65 Charlotte Brontë, The Letters of Charlotte Brontë, I829-I847, ed. Margaret Smith (Oxford: Clarendon Press, I995), 574.

66 Levine, Realistic Imagination, I 5.

67 Levine, Realistic Imagination, I 5.

68 Glen, Imagination in History, 50.

69 Glen, Imagination in History, 46.

70 Glen, Imagination in History, 35.

7I Sally Shuttleworth, Charlotte Brontë and Victorian Psychology (Cambridge: Cambridge University Press, I996), 24; for the textual history of Self-Help, and particularly its development throughout Smiles's editorship of The Leeds Times (a newspaper Brontë was known to have read), see Tim Travers, Samuel Smiles and the Victorian Work Ethic (New York: Garland Publishing, 1987), 76-8o.

72 Samuel Smiles, Self-Help; with Illustrations of Character and Conduct (London: John Murray, i 859), 277-78.

73 Sedgwick, Touching Feeling, I 3 I, original emphasis.

74 Shuttleworth, Victorian Psychology, I 27.

75 Shuttleworth, Victorian Psychology, I 46-47. 
76 Glen, Imagination in History, I9, 43-44.

77 Terry Eagleton, Myths of Power (Basingstoke: MacMillan Press, I 988), 43.

78 Malone, "We Have Learnt to Love Her More than Her Books": The Critical Reception of Brontë's Professor', i 80.

79 Neville Newman, "Workers, Gentlemen and Landowners": Identifying Social Class in The Professor and Wuthering Heights', Brontë Society Transactions 26, no. I (200I): IO-II.

80 Jennifer Ruth, 'Between Labor and Capital: Charlotte Bronte's Professional Professor', Victorian Studies 45, no. 2 (2003): 279-303, https://doi.org/Io .I353/vic.2003.0098.

8 I Glen, Imagination in History, 35.

82 Glen, Imagination in History, 43.

83 Asa Briggs, Victorian People: A Reassessment of Persons and Themes, I85I-67 (Chicago: University of Chicago Press, I973), I I 8.

84 Glen, Imagination in History, 35; Shuttleworth, Victorian Psychology, I 46.

85 Nancy Bauer has recently argued that the ethical critique of pornography requires a more literal understanding of the logic of the fictional world depicted by pornographic representation, especially as it operates differently from the actual world which it superficially mimics: 'No one in the pornutopia has a reason to lose interest in or fear or get bored by sex; no one suffers in a way that can't be cured by it; no one is homeless or dispossessed or morally or spiritually abused or lost. When Daddy fucks Becky, she doesn't experience it as rape. She come'. How to Do Things with Pornography (Cambridge, MA: Harvard University Press, 2015), 5. Likewise, what it means for a novel character to experience years of abject labour conditions is not exactly the same as what it means for a historical person to do so; this book argues that a recognition of this flexible correspondence enriches, rather than deflates, the meaningful value and function of literature for life.

86 Brown, 'Beloved Objects', 400.

87 Barthes, The Rustle of Language, 129.

88 Ruth, 'Between Labor and Capital', 295.

89 Sedgwick, Touching Feeling, I 50; see also Berlant's interpretation of reparative reading as 'a theory of being [...] Sedgwick's mode of reading is to deshame fantasmatic attachment so as to encounter its operations as knowledge'. Lauren Berlant, Cruel Optimism (Durham, NC: Duke University Press, 2OII), I 22 .

\section{Notes to Chapter Three}

I Henry James, Literary Criticism: Essays on Literature, American Writers, English Writers, ed. Leon Edel and Mark Wilson, vol. I (New York: The Library of America, I984), I33I.

2 James, Literary Criticism, I:I33 I-32.

3 James R. Kincaid, The Novels of Anthony Trollope (Oxford: Clarendon Press, I977), 7. 
4 Anna Jameson, The Diary of an Ennuyee (London: Henry Colburn, I 826), 3 I I for the European history of the improvvisatore and their reception by the English Romantics, see Angela Esterhammer's work in 'The Cosmopolitan Improvvisatore: Spontaneity and Performance in Romantic Poetics', European Romantic Review I6, no. 2 (2005): I 53-65; and in 'The Improvisation of Poetry, I750-I 850', in The Oxford Handbook of Critical Improvisation Studies, ed. George E. Lewis and Benjamin Piekut, vol. I (Oxford: Oxford University Press, 2016), 239-54.

5 'Improvvisatori', The Penny Magazine of the Society for the Diffusion of Useful Knowledge, April 20, I839, I46-47.

6 Jameson, Ennuyée, 3 I 7.

7 Henry James, The Tragic Muse (London: MacMillan and Co., I92I), xi.

8 Anthony Trollope, Barchester Towers, ed. John Bowen (Oxford: Oxford University Press, 20I4), 24I. Further references to this edition will be incorporated into the text.

9 James, Essays on Literature, I:I 343.

Io Anthony Trollope, Orley Farm, ed. Francis O'Gorman (Oxford: Oxford University Press, 2018), I6.

I I Kincaid, Anthony Trollope, 3-4.

I 2 James, Essays on Literature, I:I 343.

I 3 'Anthony Trollope', Macmillan's Magazine, no. 44 (I 883): 47-56; quoted in Robert D. Aguirre, 'Cold Print: Professing Authorship in Anthony Trollope's An Autobiography', Biography 25, no. 4 (2002): 569.

I 4 Carolyn Dever, 'Trollope, Seriality, and the "Dullness" of Form', Literature Compass 7, no. 9 (2010): 865.

I5 William A. Cohen, 'The Palliser Novels', in The Cambridge Companion to Anthony Trollope, ed. Carolyn Dever and Lisa Niles (Cambridge: Cambridge University Press, 2010), 47; George Levine, Darwin and the Novelists: Patterns of Science in Victorian Fiction (Chicago: University of Chicago Press, I991), I95; L. J. Swingle, Romanticism and Anthony Trollope: A Study in the Continuities of Nineteenth-Century Literary Thought (Ann Arbor: University of Michigan Press, I990), 74-75.

I6 James, Essays on Literature, I:I338.

I7 D. A. Miller, Narrative and Its Discontents: Problems of Closure in the Traditional Novel (Princeton: Princeton University Press, I98I), xiv, ix, emphasis added.

I 8 James, Essays on Literature, I:I 343.

I9 Bertrand Russell, The Problems of Philosophy, ed. John Skorupski (Oxford: Oxford University Press, I998), 47.

20 Russell, The Problems of Philosophy, 47.

2 I In narratology, this is more usually framed as a problem of communication and pertinence (rather than, as I suggest here, a mechanism for narrative), or a way of typologising genres of fiction by degrees of implied incompleteness. See Marie-Laure Ryan, 'Fiction As a Logical, Ontological, and Illocutionary Issue', Style I8, no. 2 (I984): I29-3I; see also Doležel's reviews of this 
problem in 'Mimesis and Possible Worlds', Poetics Today 9, no. 3 (I988): 486-87; and in Lubomír Doležel, 'Fictional Worlds: Density, Gaps, and Inference', Style 29, no. 2 (I995): 20 I-I 4.

22 As I argued in the first chapter, to add an imaginary soldier to a historical military campaign, or posit an extra address (22IB) to those which actually exist on London's Baker Street, is exemplary of the novel's distinctive, utopian fictionality.

23 Lewis, 'Truth in Fiction', 42; see a similar argument in Nicholas Wolterstorff's variation on a critical commonplace: 'We shall never know how many children had Lady Macbeth in the worlds of Macbeth [...] because there is nothing of the sort to know'. Works and Worlds of Art (Oxford: Clarendon Press, 1980), 133; cited by Doležel as an exemplary case of 'The property of incompleteness [which] implies that many conceivable statements about literary fictional worlds are undecidable'. 'Mimesis and Possible Worlds', 486.

24 Miller, Discontents, ix.

25 Jameson, Commonplace Book, I3 I, emphasis added.

26 Miller, Discontents, 365; for a similar model of narrative desire as moving from insufficiency towards totality, see Peter Brooks, Reading for the Plot: Design and Intention in Narrative (Cambridge, MA: Harvard University Press, 1996), 94. '[W] are able to read present moments - in literature and, by extension, in life - as endowed with narrative meaning only because we read them in anticipation of the structuring power of those endings that will retrospectively give them the order and significance of plot'.

27 Anthony Trollope, The Last Chronicle of Barset, ed. Helen Small (Oxford: Oxford University Press, 2015), 729. Further references to this edition will be incorporated into the text.

28 Anthony Arthur, "The Death of Mrs. Proudie: "Frivolous Slaughter" or Calculated Dispatch?', Nineteenth-Century Fiction 26, no. 4 (1972): 478; such criticism recurrently identifies as anomalous or idiosyncratic behaviours which novelists in this period clearly had in common. My broader argument is to reintegrate these anomalies into a coherent practice of fiction. 'Perhaps it is only Thackeray, among the great, who seems to find a positively wilful pleasure in damaging his own story [...] insisting in so many words on his freedom to say what he pleases about his men and women and to make them behave as he will'. Percy Lubbock, The Craft of Fiction (London: Jonathan Cape, 1954), 87-88.

29 Sophie Ratcliffe, 'The Episodic Trollope and An Editor's Tales', Victorian Studies 58, no. I (2015): 6I.

30 Kincaid, Anthony Trollope, 3.

3 I Arthur, 'Death of Mrs. Proudie', 482.

32 Arthur, 'Death of Mrs. Proudie', 484.

33 Arthur, 'Death of Mrs. Proudie', 480. While I emphasise this here as a practice of literary production, in the next chapter on Thackeray's novel series, I examine the reading experience engendered by such intertextual connections of a fictional world. 
34 Sedgwick, Touching Feeling, I 30.

35 Arthur, 'Death of Mrs. Proudie', 478.

36 John A. Sutherland, 'Trollope at Work on The Way We Live Now', Nineteenth-Century Fiction 37, no. 3 (I982): 439.

37 Sutherland, 'Trollope at Work', 439.

38 James, Tragic Muse, xi.

39 David Russell, Tact: Aesthetic Liberalism and the Essay Form in NineteenthCentury Britain (Princeton: Princeton University Press, 2018), 29-30.

40 Russell, Tact, 29.

4I Russell, Tact, 29.

42 Ruth ApRoberts, Trollope: Artist and Moralist (London: Chatto, I97I), 52.

43 ApRoberts, Trollope, 52, 42, 39, original emphases.

44 On objections to apRoberts's 'relativist' view of Trollope, see Roger L Slakey, 'Trollope's Case for Moral Imperative', Nineteenth-Century Fiction 28, no. 3 (I973): 305-20; and Andrew Wright, Anthony Trollope: Dream and Art (London: MacMillan Press, I983), I 53.

45 ApRoberts, Artist and Moralist, 52.

46 ApRoberts, Artist and Moralist, 39.

47 Andrew H. Miller, The Burdens of Perfection: On Ethics and Reading in Nineteenth-Century Literature (Ithaca, NY: Cornell University Press, 2008), 95.

48 'casuistry, n.', OED Online (Oxford University Press, 2010), www.oed.com/ view/Entry/28642, accessed I9 June 2018; see George Eliot's ambivalence on this point: 'The casuists have become a byword of reproach; but their perverted spirit of minute discrimination [...] discern[s] that the mysterious complexity of our life is not to be embraced by maxims[.]' The Mill on the Floss, ed. Gordon S. Haight (Oxford: Clarendon Press, I980), 437-38.

49 Anthony Trollope, Eustace Diamonds, ed. Helen Small (Oxford: Oxford University Press, 20I I), 33; quoted in Kincaid, Anthony Trollope, I 5.

50 Anthony Trollope, The Prime Minister, ed. Nicholas Shrimpton (Oxford: Oxford University Press, 20I I), 9; Miller, Burdens of Perfection, 95.

5 I Miller, Burdens of Perfection, 95.

52 ApRoberts, Artist and Moralist, 52.

53 Matthew Sussman, 'Optative Form in Anthony Trollope's The Small House at Allington', Nineteenth-Century Literature 7I, no. 4 (2017): 498.

54 Anthony Trollope, The Small House at Allington, ed. Dinah Birch (Oxford: Oxford University Press, 20 I 5), xii, xiii. Further references to this edition will be incorporated into the text.

55 Amanda Anderson, 'Trollope's Modernity', ELH 74, no. 3 (2007): 509-34.

56 Stephen Wall, Trollope and Character (London: Faber \& Faber, I988), 34-35.

57 Sussman, 'Optative Form', 489.

58 J. Hillis Miller, Communities in Fiction (New York: Fordham University Press, $2015), 77$.

59 As Betty Cannon puts it, one falls into Sartre's definition of bad faith 'if I take one or both of two positions about reality: If I pretend either to be free in a world without facts or to be a fact in a world without freedom'. Sartre and 
Psychoanalysis: An Existential Challenge to Clinical Meta-Theory (Lawrence: University Press of Kansas, 1991), 46. The experience of an explicitly subjective world with consistent, objective facts represents the strategic redeployment of these operations of bad faith in an authentic act of play.

60 Wall, Trollope and Character, 34.

6I Anderson, 'Trollope's Modernity'; Wall, Trollope and Character, 59.

62 ApRoberts, Artist and Moralist, 43. It should be noted that apRoberts argues strongly against Trollope's arbitrariness or artificiality, which would constitute 'an unethical manipulation of data' in the moral situations he constructs. My argument, of course, is precisely that this manipulation constitutes an ethical process.

63 Miller, Burdens of Perfection, 94.

64 Quoted in Ratcliffe, 'Episodic Trollope', 6r.

65 Helena Michie, 'Rethinking Marriage: Trollope's Internal Revision', in The Routledge Research Companion to Anthony Trollope, ed. Deborah Denenholz Morse, Margaret Markwick, and Mark W. Turner (Oxford: Routledge, 2017), I 54 .

66 Michie, 'Rethinking Marriage', I 55.

67 Sussman, 'Optative Form', 493.

68 Anthony Trollope, Can You Forgive Her?, ed. Dinah Birch (Oxford: Oxford University Press, 2012), 95.

69 On the extent to which the difference between these two characters is a gendered one, see Michie's argument that 'Thinking for all Trollope characters, but especially for women, happens under a set of social and generic constraints' that are particularly palpable for middle- to upper-class women of Alice's position. 'Rethinking Marriage', I55; see also Margaret F. King's argument on Trollope's attitude towards contemporary 'learned ladies' bringing female decision-making into new scrutiny, in "Certain Learned Ladies': Trollope's Can You Forgive Her? And the Langham Place Circle', Victorian Literature and Culture 2I (1993): 307-26; for Sussman, 'Gender is among the variables that cause the surface details between the two novels to differ [...] but the underlying condition is the same [...] it is this universality of the optative[.]' 'Optative Form', 502.

70 Wall, Trollope and Character, 63.

7 I Sussman, 'Optative Form', 496.

72 Miller, Burdens of Perfection, 95, 98.

73 Ratcliffe, 'Episodic Trollope', 59.

74 For a full account of Trollope's working process, see Mary Hamer, Writing by Numbers: Trollope's Serial Fiction (Cambridge: Cambridge University Press, 1987).

\section{Notes to Chapter Four}

I G. K. Chesterton, The Collected Works of G. K. Chesterton: Chesterton on Dickens, ed. Alzina Stone Dale, vol. I5 (San Francisco: Ignatius Press, I989), 403. 
2 Chesterton, On Dickens, I 5:404.

3 Chesterton, On Dickens, I 5:403.

4 Chesterton, On Dickens, I 5:403.

5 Chesterton, On Dickens, I 5:403.

6 James, Essays on Literature, I:I 352.

7 Henry James, Literary Criticism: French Writers, Other European Writers, the Prefaces to the New York Edition, ed. Leon Edel and Mark Wilson, vol. 2 (New York: The Library of America, I984), 4I.

8 Geoffrey Tillotson, Thackeray the Novelist (London: Methuen \& Co., I954), 5 .

9 'stock, n. 3c.', OED Online (Oxford University Press, 2010), www.oed.com/ view/Entry/I 90595 , accessed I9 June 2018.

Io James, Tragic Muse, xi.

I I James, Tragic Muse, xi.

I 2 Chesterton, On Dickens, I 5:404.

I 3 Tillotson, Thackeray the Novelist, I-2.

I 4 James, French Writers, 2:4I.

I 5 Chesterton, On Dickens, I 5:403.

I6 William Makepeace Thackeray, 'Proposals for a Continuation of Ivanhoe', Fraser's Magazine for Town and Country 34, no. 200 (August I 846): 237.

I7 William Makepeace Thackeray, A Collection of Letters of Thackeray, I847-I855, ed. Jane Octavia Brookfield (New York: Scribner, I 887), 87.

I 8 Thackeray, 'Proposals', 237.

I9 Thackeray, 'Proposals', 237.

20 'wallow, v.', OED Online (Oxford University Press, 2010), www.oed.com/ view/Entry/225332, accessed I9 June 2018.

2 I Gaskell, Letters, 602.

22 James, Essays on Literature, I:977.

23 William Allingham, 'Visits to Aldsworth', in Tennyson: Interviews and Recollections, ed. Norman Page (London: MacMillan Press, I983), I 34.

24 Samuel Taylor Coleridge, Biographia Literaria, ed. J. Shawcross, vol. I (Oxford: Oxford University Press, I907), 34, original emphasis.

25 Henrietta Eliza Vaughan Stannard, née Palmer, also wrote under the pseudonyms 'John Strange Winter' and 'Violet Whyte', and was also referred to by her husband's name, Mrs Arthur Stannard.

26 'Novels and their Endings' in John Ruskin, The Works of John Ruskin, ed. E. T. Cook and Alexander Wedderburn, vol. 34 (London: George Allen, I 908), 605. Further references to this edition will be incorporated into the text.

27 James, French Writers, 2:4I.

28 Allingham, 'Visits to Aldsworth', I 34.

29 Auyoung, When Fiction Feels Real, 97.

30 F. R. Leavis, The Great Tradition: George Eliot, Henry James, Joseph Conrad (New York: George W. Stewart, I950), 2 I.

3 I John Strange Winter, Bootles' Children (London: F. V. White \& Co., I 888), unpaginated. 
32 John Plotz, 'Serial Pleasures: The Influence of Television on the Victorian Novel', Romanticism on the Net, no. 63 (2014): para. 26, http://id.erudit.org/ iderudit/ I0256I 9 ar.

33 Plotz, 'Serial Pleasures', para. I9.

34 James, Essays on Literature, I:977.

35 Plotz, 'Serial Pleasures', para. I9.

36 Holly Furneaux, Queer Dickens (Oxford: Oxford University Press, 2009), 67.

37 Ben Winyard, "May We Meet Again”: Rereading the Dickensian Serial in the Digital Age', I9: Interdisciplinary Studies in the Long Nineteenth Century, no. 21 (2015): para. 3, www.I 9.bbk.ac.uk/articles/I0.I6995/ntn.737/.

38 See John M. Picker, 'George Eliot and the Sequel Question', New Literary History 37, no. 2 (2006): 36I-88.

39 Wolfgang Iser, Prospecting: From Reader Response to Literary Anthropology (Baltimore: Johns Hopkins University Press, I989), I I.

40 Winyard, “May We Meet Again”, para. 3.

4I Levine, Realistic Imagination, I 43.

42 D. A. Miller, The Novel and the Police (Berkeley: University of California Press, I988), I4I.

43 Plotz, 'Serial Pleasures', para. 27.

44 Picker, 'George Eliot and the Sequel Question', 378.

45 Elisha Cohn, Still Life (Oxford: Oxford University Press, 2016), 62, 63.

46 Coleridge, Biographia Literaria, I:34.

47 Brontë, Villette, I05.

48 Brown, 'Beloved Objects: Mourning, Materiality, and Charlotte Brontë's "Never-Ending Story", 403.

49 Root-Bernstein, Inventing Imaginary Worlds, 4I.

50 Jameson, Commonplace Book, I 3 I.

5 I Shuttleworth, Mind of the Child, 87.

52 Root-Bernstein, Inventing Imaginary Worlds, 23.

53 Berlant, Cruel Optimism, 24, original emphasis; Root-Bernstein, Inventing Imaginary Worlds, 23.

54 Allingham, 'Visits to Aldsworth', I 34.

55 James, Essays on Literature, I:977; Berlant, Cruel Optimism, 24, emphasis added.

56 Charles Dickens, Master Humphrey's Clock, vol. I (London: Chapman and Hall, I 840), iii.

57 Furneaux, Queer Dickens, 86-87.

58 Winter, Bootles' Children, unpaginated.

59 'Farewell to Angria' in Brontë et al., Tales, 3 I4. Further references to this edition will be incorporated into the text.

6o Linda K. Hughes and Michael Lund, The Victorian Serial (Charlottesville: University Press of Virginia, I991), Io.

6I Philip Collins, ed., Thackeray: Interviews and Recollections, vol. 2 (London: MacMillan Press, I989), 250. 
62 Amy Barter, Stories of Pendennis and the Charterhouse, from Thackeray (London: George G. Harrap \& Company, I9I2).

63 Leah Price, The Anthology and the Rise of the Novel (Cambridge: Cambridge University Press, 2000), 6-7.

64 Barter, Stories of Pendennis, 36-37.

65 Barter, 36.

66 William Makepeace Thackeray, The Adventures of Philip On His Way through the World Shewing Who Robbed Him, Who Helped Him, and Who Passed Him By, ed. Judith Law Fisher (Ann Arbor: University of Michigan Press, 2010), 533; see also Auyoung's flagging of this passage as self-reflexive of the reading experience of closure. 'The farewells expressed in this last scene double as a means by which the text figuratively takes leave of the reader'. When Fiction Feels Real, 99.

67 William Makepeace Thackeray, The Newcomes: Memoirs of a Most Respectable Family, ed. Andrew Sanders (Oxford: Oxford University Press, I995), I7. Further references to this edition will be incorporated into the text.

68 Nicholas Dames, The Physiology of the Novel: Reading, Neural Science, and the Form of Victorian Fiction (Oxford: Oxford University Press, 2007), I09.

69 Juliet McMaster, 'Theme and Form in The Newcomes', Nineteenth-Century Fiction 23, no. 2 (1968): I80.

70 Dames, Physiology, Io9.

7I Levine, Forms, Io8.

72 Levine, Forms, Io8.

73 Levine, Forms, I25; see also Levine's previous work in The Serious Pleasures of Suspense (Charlottesville: University of Virginia Press, 2003).

74 'The Newcomes', Athenaeum, August 4, I855, I499; quoted in Dames, Physiology, 106.

75 Levine, Forms, I08.

76 Levine, Forms, I 28.

77 G. Levine, Realistic Imagination, I39-40.

78 Lawrence Charles Zygmunt, 'Thackeray and the Picaresque World' (PhD diss., University of Chicago, 2012), 46.

79 Thackeray, Vanity Fair, 2.

80 Gage McWeeny, The Comfort of Strangers: Social Life and Literary Form (Oxford: Oxford University Press, 2016), 65.

8I Chesterton, On Dickens; Zygmunt, 'Thackeray and the Picaresque World', 56.

82 Zygmunt, 'Thackeray and the Picaresque World', 56.

83 Collins, Thackeray: Interviews and Recollections, 2:2 I 6.

$84 \mathrm{McWeeny,} \mathrm{Comfort} \mathrm{of} \mathrm{Strangers,} \mathrm{66;} \mathrm{G.} \mathrm{Levine,} \mathrm{Realistic} \mathrm{Imagination,} \mathrm{I} \mathrm{53-54.}$

85 Thackeray, 'Proposals', 238.

86 Henry James, Roderick Hudson (London: MacMillan and Co., I92 I), x.

87 Chesterton, On Dickens, I 5:403.

88 Levine, Forms, I 30. 
89 Keren Eyal and Jonathan Cohen, 'When Good Friends Say Goodbye: A Parasocial Breakup Study', Journal of Broadcasting \& Electronic Media 50, no. 3 (2006): 502-3.

90 Thackeray, Roundabout Papers, 272.

9I Thackeray, Roundabout Papers, 272-73.

92 Thackeray, Roundabout Papers, 273.

93 Thackeray, Roundabout Papers, 273.

94 Thackeray, Roundabout Papers, 272.

95 Edward W. Said, Culture and Imperialism (New York: Knopf, 1994), 74; or in Raymond Williams's very similar argument, as an 'available escape route [...] [where] characters whose destinies could not be worked out within the system as given were simply put on the boat', in The Long Revolution (Westport, CT: Greenwood Press, 1975), I I 5-16; both quoted in Maia McAleavey, The Bigamy Plot: Sensation and Convention in the Victorian Novel (Cambridge: Cambridge University Press, 2015), i I6.

96 Said, Culture and Imperialism, 74; Chesterton, On Dickens, I 5:403.

97 Barter, Stories of Pendennis, 36.

98 Tillotson has also called this the 'lack of an edged shape' in Thackeray's novels, produced by 'an aspiration towards rendering the vastness of the world and the never-endingness of time'. Thackeray the Novelist, I 2.

\section{Notes to Chapter Five}

I Lewes, 'Dickens in Relation', I44.

2 Lewes, 'Dickens in Relation', I 44, original emphasis.

3 Lewes, 'Dickens in Relation', I45.

4 Lewes, 'Dickens in Relation', I 44.

5 Tyson Michael Stolte, 'Mind Reflected on Paper: Dickens, Victorian Psychology, and the First-Person Novel' (PhD diss., University of British Columbia, 2009), I.

6 Lewes, 'Dickens in Relation', I46; Henry James, 'Our Mutual Friend', The Nation, December 21, I865.

7 Lewes, 'Dickens in Relation', I46.

8 Lewes, 'Dickens in Relation', I44.

9 Lewes, 'Dickens in Relation', I 44.

Io Rosemarie Bodenheimer, Knowing Dickens (Ithaca, NY: Cornell University Press, 2007), 5.

I I As I have previously argued, such conflations of belief with experience misconceive the double consciousness involved in pretending and imagining (although Lewes distinguishes 'knowing' from 'being affected'). Lewes, 'Dickens in Relation', I45.

I2 Lowe, Insights of Sympathy, 94.

I 3 It is hard to say for certain how much of this composition is the written record of a verbal game that occurred the year before, in 1828 , and how much is 
being invented with the composition in I 829. The Brontës in this period are in the process of transitioning from writing down records of previous playnarratives and writing new narratives as a form of play in itself.

I4 Julia Mandell, 'Rules of the Games', Architecture 93, no. 7 (2004): 66.

I 5 Barthes, The Rustle of Language, I4I, original emphasis.

I6 Barthes, The Rustle of Language, I 43, I 45-46, original emphasis.

I7 Barthes, The Rustle of Language, I44, I 46.

I 8 Barthes, The Rustle of Language, I42.

I9 Barthes, The Rustle of Language, I 48.

20 James Wood, How Fiction Works (London: Vintage Books, 2010), 52 , original emphasis.

2 I As I argued in the second chapter, such repudiations are more ambivalent than they appear - Crimsworth and Frances in fact build an extravagantly successful boarding-school at the conclusion of The Professor.

22 James, Tragic Muse, xi.

23 Lowe, Insights of Sympathy, 91.

24 James, Essays on Literature, 1:958, 965.

25 Leavis, The Great Tradition, $2 \mathrm{I}$.

26 Davis, Resisting Novels, 24; quoted in Lowe, Insights of Sympathy, 76.

27 Davis, Resisting Novels, 24.

28 Sue Zemka, Time and the Moment in Victorian Literature and Society (Cambridge: Cambridge University Press, 2012), I9.

29 James Mill, Analysis of the Phenomena of the Human Mind, ed. Alexander Bain et al., vol. I (London: Longmans, Green, Reader, \& Dyer, I869), 52.

30 Mill, Analysis, I:52.

3 I Zemka, Time and the Moment in Victorian Literature and Society, 2 I.

32 Mill, Analysis, I:65.

33 Jean-Marie Schaeffer has recently described these experiences - of memory, visualisation, and hallucination - as "“virtual realities" born with biological systems of representation'. Why Fiction?, xii.

34 James Cowles Prichard, A Treatise on Diseases of the Nervous System, Part the First: Comprising Convulsive and Maniacal Affections (London: Underwood, I 822), I 26.

35 Robert MacNish, The Philosophy of Sleep (Glasgow: W. R. M'Phun, I 834), 243.

36 John Abercrombie, Inquiries Concerning the Intellectual Powers, and the Investigation of Truth (New York: Collins and Brother, I 849), 52.

37 Henry Holland, Chapters on Mental Physiology (London: Longman, Brown, Green, and Longmans, I 852 ), I I 3.

38 Prichard, Diseases of the Nervous System, I 26.

39 [Francis Jacox,] 'Hartley Coleridge', Bentley's Miscellany 45 (I 8 59): 584.

40 'Hartley Coleridge as Man, Poet, Essayist', Fraser's Magazine for Town and Country 43 (I 85 I): 504.

4I 'Hartley Coleridge', The Gentleman's Magazine (June i 85I): 58I.

42 'Review of "Poem, by Hartley Coleridge; with a Memoir of Life, by His Brother", The Christian Remembrancer 22 (I85 I): I08-9. 
43 Gallagher, 'Rise of Fictionality', 338.

44 Shuttleworth, Mind of the Child, 86-87; more or less the kind of moral failing Plato denounced as the effect of poetry in Book X of The Republic, as it appeals to our 'childish and pervasive' love for unreason. See Plato, Republic, trans. Robin Waterfield (Oxford: Oxford University Press, 2008), 6o6d6o8b, 36o-62.

45 J. Crichton-Browne, 'Psychical Diseases of Early Life', British Journal of Psychology 6 (i 860): 303.

46 'Mrs Jameson's Common-Place Book', The New Monthly Magazine, I855, I94; 'Mrs Jameson's Common-Place Book', Chamber's Journal of Popular Literature, Science and Arts 3, no. 53 (I855): 8.

47 'Hartley Coleridge', The Gentleman's Magazine, $58 \mathrm{I}$.

48 Davis, Resisting Novels, 24.

49 'Mrs Jameson's Common-Place Book', Chamber's Journal, i 855 , 8.

50 Lewes, 'Dickens in Relation', I44, emphasis added; Lewes's own work had contributed to the consensus around mental perceptions by theorising the phenomena of 'subjective sensations; that is to say, we see objects very vividly, where no such objects exist; we hear sounds of many kinds, where none of their external causes exist [...] They are indistinguishable from the sensations caused by actual contact of the objects with our organs', which in intense forms 'produce Hallucinations'. The Physiology of Common Life, vol. 2 (London: William Blackwood and Sons, i 859), 308.

5 I Lewes, 'Dickens in Relation', I45.

52 P. R. Marland, 'Seeing Things in Dickens: A Study of Representation and Hypotyposis' (PhD diss., University of Sydney, 20 I 4), 6.

53 Charles Lamb, Selected Prose, ed. Adam Phillips (Harmondsworth: Penguin, I985), 202.

54 See Adam Phillips, Going Sane (London: Penguin, 2006), 63.

55 Lamb, Selected Prose, 202.

56 Taylor Stoehr, Dickens: The Dreamer's Stance (Ithaca, NY: Cornell University Press, I965), 38.

57 Lewes, 'Dickens In Relatio', I 45.

58 'About Ejuxria and Gombroon', Bentley's Miscellany, no. 59 (I 866): 75.

59 Jacox, 'Hartley Coleridge', 75-76.

60 Abercrombie, The Intellectual Powers, 52.

6 I Marland, 'Seeing Things', 69.

62 Marland, 'Seeing Things', 67.

63 Lowe, Insights of Sympathy, 94.

64 Barthes, The Rustle of Language, I48.

65 Barthes, The Rustle of Language, I 43.

66 Marie-Laure Ryan, 'The Modes of Narrativity and Their Visual Metaphors', Style 26, no. 3 (I992): 375; see also Erik Van Ooijen's discussion of Ryan in relation to Barthes's changing concepts of textual economy, in 'The Affluence of Literature', in Narrativity, Fictionality and Literariness: The Narrative Turn 
and the Study of Literary Fiction, ed. Lars-Åke Skalin (Örebro: Örebro University Press, 2008), I25-27.

67 Lowe, Insights of Sympathy, 94.

68 Ryan, 'Modes of Narrativity', 375.

69 Lewes, 'Dickens in Relation', I46; Lewes seems therefore to be reversing associationism's terms for objects of direct sensory presence (sensations) and recalled or mental presence (ideas). As Mill despairingly admits, both 'sensation' and 'idea' are words of 'inconvenience [...] used with great latitude of meaning, both in ordinary, and in philosophical discourse'. Mill, Analysis, I:I 52.

70 Lewes, 'Dickens in Relation', I46.

7I 'wooden, Adj. 2a.', OED Online (Oxford University Press, 20I0), www.oed $. c 0 m / v i e w /$ Entry/230028, accessed I9 June 2018.

72 Crichton-Browne, 'Psychical Diseases', 303.

73 Charles Dickens, Little Dorrit, ed. Harvey Peter Sucksmith (Oxford: Clarendon Press, 1979), 5-6. Further references to this edition will be incorporated into the text.

74 Philip Collins, 'Little Dorrit: The Prison and the Critics', Times Literary Supplement, April I8, 1980, 446; Lionel Trilling, 'Little Dorrit', The Kenyon Review I 5, no. 4 (1953): 589.

75 Trilling, 'Little Dorrit', 578-79.

76 Edmund Wilson, The Wound and the Bow: Seven Studies in Literature (Cambridge: Houghton Mifflin Company, 194I), 56; J. Hillis Miller, Charles Dickens: The World of the His Novels (Cambridge, MA: Harvard University Press, 1958), 228-29.

77 For which, see John Carey's strong contention: 'We're told that the repetition [of the prison symbol] unifies the novel, and that it reveals a deeper meaning. This deep meaning is represented by maxims like "Society is a prison" or "All the world's a prison", [...] using the word "prison", we realize, only in some enfeebled figurative sense - a sense which no one who had ever really been in prison would condone'. The Violent Effigy: A Study of Dickens' Imagination (London: Faber \& Faber, I979), i I 4.

78 Barthes, The Rustle of Language, 146.

79 'Introduction' in Charles Dickens, Little Dorrit, ed. John Holloway (Harmondsworth: Penguin, 1973), I5; Charles Dickens, The Letters of Charles Dickens, $1856-1858$, ed. Graham Storey and Kathleen Tillotson, vol. 8 (Oxford: Clarendon Press, 1995), 79, 280; quoted in Collins, 'Little Dorrit: The Prison and the Critics', 446.

80 See Paul D. Herring, 'Dickens' Monthly Number Plans', Modern Philology 64, no. I (I966): 26.

8 I Trilling, 'Little Dorrit', 578.

82 George Orwell, Critical Essays (London: Secker \& Warburg, 1946), 52.

83 Michel Foucault, Discipline and Punish, trans. Alan Sheridan (London: Harmondsworth, I979), 205. 
84 F. R. Leavis and Q. D. Leavis, Dickens the Novelist (London: Chatto \& Windus, 1972), 222.

85 George Gissing, Charles Dickens: A Critical Study (New York: Dodd, Mead and Company, I 898), I 34 .

86 As with Jane Eyre, going hungry at the Lowood School, who makes a habit of 'prepar[ing] in imagination the Barmecide supper of hot roast potatoes, or white bread and new milk, with which I was wont to amuse my inward cravings' (JE 87). Or with Lamb's depiction of 'Captain Jackson', maintaining a spirit of hospitality in poverty: 'You saw with your bodily eyes indeed what seemed a bare scrag - cold savings from the foregone meal - remnant hardly sufficient [...] But in the copious will - the revelling imagination of your host [...] no end appeared to the profusion'. To drink, 'Wine we had none [...] but the sensation of wine was there [...] Shut your eyes, and you would swear a capacious bowl of punch was foaming in the centre'. Essays of Elia, Letters, and Rosamund, A Tale (Paris: Baudry's European Library, I 835), 209. Such studies in illusory food are clearly interested in the potential resources of a sensuous imagination in historical conditions of need.

87 Ryan, 'Modes of Narrativity', 375.

88 Barbara Hardy, Dickens and Creativity (London: Continuum, 2008), I 24.

89 'castle, n. II.', OED Online (Oxford University Press, 2010), www.oed .com/view/Entry/2858I, accessed i9 June 20 I 8.

90 Ryan, 'Parallel Universes to Possible Worlds', i 56.

9I Hardy, Dickens and Creativity, Io9.

92 Trilling, 'Little Dorrit', 579.

93 Crichton-Browne, 'Psychical Diseases', 303.

94 Prichard, Diseases of the Nervous System, I 28; or as Abercrombie noted, 'Visions of the imagination which have formerly been indulged in, of that kind which we call waking dreams, or castle-building [...] [are] now believed to have a real existence'. The Intellectual Powers, 234.

95 Exemplifying, as Robert Douglas-Fairhurst puts it, 'how adept Dickens was becoming at creating complications for himself and then tidying them away'. Charles Dickens, ed. Adrian Poole, The Cambridge Companion to English Novelists (Cambridge: Cambridge University Press, 2009), I36.

96 Stoehr, The Dreamer's Stance, 64.

97 See Stoehr, The Dreamer's Stance, 63-64.

98 Trilling, 'Little Dorrit', 578.

99 Quoted and translated in Erich Auerbach, Time, History, and Literature: Selected Essays of Erich Auerbach, ed. James I. Porter, trans. Jane O. Newman (Princeton: Princeton University Press, 20I4), 86.

Ioo See also Wolfgang Mieder, Behold the Proverbs of a People (Jackson: University Press of Mississippi, 2014), 422-25.

Io I Auerbach, Time, History, and Literature, 86.

IO2 Forbes Winslow, On the Preservation of the Health of Body and Mind (London: Henry Renshaw, I 842), I72, emphasis added.

I03 'Hartley Coleridge as Man, Poet, Essayist', 605. 
I04 'Mrs Jameson's Common-Place Book', The New Monthly Magazine, I 855 , I96.

I05 Davis, Resisting Novels, 24.

Io6 See also Elaine Scarry's discussion about the projections from Proust's magic lantern, as a metonym for how Swann's Way materialises the solid walls of Marcel's childhood bedroom. Dreaming by the Book (Princeton: Princeton University Press, 200I), I 2.

I07 Lewes, 'Dickens in Relation', I45.

Io8 Lewes, 'Dickens in Relation', I45.

I09 Venice seems to represent, for Dickens, a particularly apt setting for this kind of mental state. His accounts of visiting the city emphasise the hallucinogenic quality of 'this strange Dream upon the water', wondering at the architecture that rises unstably - like the aerial castle - from its 'unsubstantial ground'. Charles Dickens, Pictures from Italy, ed. Kate Flint (London: Penguin, I998), 249, 256.

I I B Barthes, The Rustle of Language, I 44.

I I I Leavis and Leavis, Dickens the Novelist, 222.

I 2 Trilling, 'Little Dorrit', 589; Hardy, Dickens and Creativity, I09.

I 3 Stoehr, The Dreamer's Stance, 38.

I 4 Stoehr, The Dreamer's Stance, 64.

I I 5 As Jolene Zigarovich has pointed out, 'in the manuscripts, proofs, and first editions of the novel, the names in all the epitaphs are small-capped, which resembles epitaph typography [...] Chivery's depresentification, his spatial self-distance, is not confined to a mode of verbal narration'. 'Proleptic Death in Dickens's A Christmas Carol and Little Dorrit', ANQ: A Quarterly Journal of Short Articles, Notes and Reviews 29, no. 2 (2016): 80. Alongside the 'hypotyposis' of John's verbal description of his future, these epitaphs form a graphic representation of what he imagines, such that - bizarrely - the character's imagined objects achieve a more visual, spatial, and material existence in the novel's print than in the novel's world. Like the extended metaphor of the castle in the air, the imagined world of John's prisonchurchyard assumes its own reality for the reader as its objects materialise on the page.

\section{Notes to the Conclusion}

I Grant Rodiek, 'The Sims 4 Patch Notes', The Sims 4, 20 I 8, https://help.ea.com/ en-gb/help/the-sims/the-sims-4/the-sims-4-updates/, accessed I9 June 20 I 8.

2 'Description of the Security Update for Word 2016: July Io, 20 I 8', Microsoft Support, 20I8, https://support.microsoft.com/en-us/help/4022218/descrip tion-of-the-security-update-for-word-201 6-july-io-20 I 8.

3 Chris Baker, 'Will Wright Wants to Make a Game out of Life Itself, Wired Magazine, July 201 2, https://www.wired.com/2012/07/mf_iconswright/.

4 Diane Nutt and Diane Railton, 'The Sims: Real Life as Genre', Information, Communication \& Society 6, no. 4 (2003): 584. 
5 Gallagher, 'Rise of Fictionality', 340.

6 Felski, Limits of Critique, I 2.

7 'The work of ideology is to present the position of the subject as fixed and unchangeable [...] [in] human nature and the world of human experience, and to show possible action as an endless repetition of "normal", familiar action. To the extent that the classic realist text performs this work, classical realism is an ideological practice'. Catherine Belsey, Critical Practice (London: Routledge, 200I), 74 .

8 Emma Butcher, The Brontës and War: Fantasy and Conflict in Charlotte and Bronwell Brontë's Youthful Writings (London: Palgrave Macmillan, 2019), 135 .

9 See Robert Sparrow, 'Robots, Rape, and Representation', International Journal of Social Robotics 9, no. 4 (2017): 465-77.

Io These subjects have also explicitly converged in recent scholarship. See S. L. Patridge, 'Pornography, Ethics, and Video games', Ethics and Information Technology I5 (2013): 25-34; A. W. Eaton, 'A Sensible Antiporn Feminism', Ethics I I7, no. 4 (2007): 674-7 I 5.

I I Bauer, How to Do Things with Pornography, 6.

I 2 'The thing about playing is always the precariousness of the interplay of personal psychic reality and the experience of control of actual objects. This is the precariousness of magic itself, magic that arises from intimacy, in a relationship that is found to be reliable'. D. W. Winnicott, Playing and Reality (London: Routledge Classics, 2005), 64.

I 3 Davis, Resisting Novels, 103. 